\title{
Amino Sugars in the Cell Walls of Pseudomonas Species
}

\author{
By S. G. WILKINSON AND K. A. CARBY \\ Department of Chemistry, University of Hull, Hull, HU6 ${ }_{7} R X$
}

(Accepted I April 1971)

SUMMARY

Fucosamine has been identified as a component of the walls of Pseudomonas denitrificans and $P$. fragi, and quinovosamine as a component of the walls of $P$. fluorescens, $P$. mucidolens, $P$. putida, $P$. stutzeri, $P$. syncyanea and $P$. synxantha. A third amino sugar, present in the walls of $P$. synxantha and possibly in those of $P$. fluorescens, was apparently 3-amino-3,6-dideoxyglucose.

\section{INTRODUCTION}

Bacterial walls contain a wide variety of unusual amino sugars, including 2-amino-2,6dideoxyhexoses and 3-amino-3,6-dideoxyhexoses. In Gram-negative bacteria such compounds occur in the lipopolysaccharide of the wall (Lüderitz, Jann \& Wheat, 1968). Although lipopolysaccharides from members of the Enterobacteriaceae have been the most widely studied, the finding of fucosamine (2-amino-2,6-dideoxygalactose) in lipopolysaccharides from strains of Pseudomonas aeruginosa (Fensom \& Gray, I969; Suzuki, I969) suggested that such compounds might be widely distributed. During a study of the walls of Pseudomonas species sensitive to ethylenediaminetetraacetic acid (Wilkinson, 1970), several unidentified compounds thought to be amino sugars were detected. This paper reports the identification of two of these compounds (previously designated Unknowns IV and VI) as quinovosamine (2-amino-2,6-dideoxyglucose) and fucosamine, respectively. A third compound (Unknown V) is apparently 3-amino-3,6-dideoxyglucose. Since the completion of this work, the isolation of D-quinovosamine from a strain of $P$. aeruginosa has been reported (Suzuki, Suzuki \& Fukasawa, 1970).

\section{METHODS}

Organisms and preparation of cell walls. Walls were prepared from Pseudomonas denitrificans (NCIB 8376), P. fluorescens (NCTC 10038), P. fragi (NCIB 8542), P. mucidolens (NCTC 8068), P. putida (NCIB 9034), P. stutzeri (NCIB 9040), P. syncyanea (NCTC 9943) and P. synxantha (NCIB 8I78) as described previously (Wilkinson, I970).

Isolation of amino sugars. The following procedure was used to isolate samples of Unknown IV (from Pseudomonas putida), Unknown VI (from $P$. fragi), a mixture of Unknowns IV and V (from $P$. synxantha), and fucosamine (from the specific polysaccharide of Pneumococcus type XII; Cifonelli, Rebers, Perry \& Jones, 1966). The walls and pneumococcal polysaccharide were hydrolysed for $4 \mathrm{~h}$. at $105^{\circ}$ with $6 \cdot \mathrm{I} \mathrm{N}-\mathrm{HCl}$. After neutralization with Dowex 2 resin in the bicarbonate form, the hydrolysates were filtered and dried. The residues were subjected to preparative electrophoresis on Whatman no. 3 paper for $2 \mathrm{~h}$. at about $20 \mathrm{~V} / \mathrm{cm}$., using aqueous pyridine + acetic acid buffer ( $\mathrm{pH} 5 \cdot 3$; Lüderitz et al. I968). Substances having a mobility equal to or slightly greater than that of glucosamine were detected by spraying guide strips with ninhydrin and were eluted. Amino sugars present 
in the eluates were separated from each other (except for Unknowns IV and V from $P$. synxantha) and from basic amino acids by preparative paper chromatography on waterwashed Whatman no. I paper, using solvent system A descending for I 2 to I $4 \mathrm{~h}$. Amino compounds were again located by spraying guide strips with ninhydrin, and were eluted using deionized water.

Paper chromatography. Analytical chromatography was done on Whatman no. I paper using the following solvent systems: $A$, ethyl acetate + pyridine + water + acetic acid $(5+5+3+\mathrm{I}$, by vol. $) ; \mathrm{B}, n$-butanol + acetic acid + water $(5+\mathrm{I}+2$, by vol. $) ; \mathrm{C}, n$-butanol + pyridine + water $(6+4+3$, by vol. $)$; $\mathrm{D}, n$-butanol + ethanol + water $(13+8+4$, by vol. $)$; E, sec-butanol $+88 \%$ formic acid + water $(15+3+2$, by vol. $) ; F$, phenol + water + aq. ammonia sp.gr. $0.88(80+20+\mathrm{I}$, by $w \mathrm{t}) ; \mathrm{G}$, the upper phase of ethyl acetate + pyridine + water $(5+2+5$, by vol.); $\mathrm{H}$, the upper phase of $n$-butanol + ethanol + water + aq. ammonia sp.gr. $0.88\left(40+10+49+\mathrm{r}\right.$, by vol.). Spots were detected using ninhydrin, alkaline $\mathrm{AgNO}_{3}$ (Trevelyan, Procter \& Harrison, 1950), aniline phosphate, the Elson-Morgan reagents (Partridge, 1948) and the reagents of Edward \& Waldron (1952).

$N$-acetylation of amino sugars. This was done as described by Strominger, Park \& Thompson (1959). Solutions containing the $N$-acetyl derivatives were deionized by passage down columns containing Dowex 50 resin (hydrogen form) overlying Dowex 2 resin (bicarbonate form).

Reduction of amino sugars. Reduction using $\mathrm{NaBH}_{4}$ was done by the method of Jann \& Jann (1968). The amino sugar alcohols formed were subjected to high voltage electrophoresis in molybdate buffer (pH 5.0) as described by Mayer \& Westphal (I968). Spots were detected using alkaline $\mathrm{AgNO}_{3}$.

Degradation of amino sugars by ninhydrin. This was done by the method of Spiro (I966). Neutral sugars formed were detected after paper chromatography using solvent systems $G$ and $\mathrm{H}$.

Oxidation of amino sugars by periodate. To a sample (about $0.25 \mu \mathrm{mole}$ ) of amino sugar dissolved in cooled, deionized water (100 $\mu \mathrm{l}$.) was added $17 \mathrm{~mm}-\mathrm{NaIO}_{4}$ (AnalaR, $150 \mu \mathrm{l}$.), and oxidation was allowed to proceed in the dark at $4^{\circ}$. Samples (Io $\mu \mathrm{l}$.) were taken periodically for the estimation of residual periodate by the method of Avigad (I969). Further samples $(50 \mu$ l.) were eventually taken for the estimation of acetaldehyde by the method of Kabat \& Mayer (I96I): the formation of acetaldehyde was confirmed by using a modification of the method (Simmons, 1969) which incorporates a micro-distillation.

Analytical methods. Amino sugars were estimated by reaction with ninhydrin using a Technicon AutoAnalyzer. The method of Park \& Johnson (1949) was used for the estimation of reducing sugars and the method of Rondle \& Morgan (1955) for the estimation of 2-amino-2-deoxyhexoses, using glucosamine as a standard in both cases. The reaction with cysteine- $\mathrm{H}_{2} \mathrm{SO}_{4}$ (Dische, 1962) was used for the detection of 6-deoxyhexoses, and the method of Ashwell, Brown \& Volk (I965) as a test for 3-acetamido-3-deoxyhexoses.

\section{RESULTS}

The unidentified, ninhydrin-positive compounds Unknowns IV, V and VI were considered to be amino sugars because of their behaviour during ion-exchange chromatography using the AutoAnalyzer (Wilkinson, 1970). Unknown IV apparently occurred in Pseudomonas fluorescens, $P$. mucidolens, $P$. putida, $P$. stutzeri, $P$. syncyanea and $P$. synxantha, Unknown $\mathrm{V}$ in $P$. fluorescens and $P$. synxantha, and Unknown VI in $P$. denitrificans and $P$. fragi. For the isolation and detailed study of these compounds, previously analysed 
batches of walls (Wilkinson, 1970) from the following bacteria were chosen: P. putida (because it contained the largest amount of Unknown IV), $P$. synxantha (because the alternative, $P$. fluorescens, contained galactosamine in addition to Unknown $\mathrm{V}$ and the other amino sugars present in $P$. synxantha), and $P$. fragi (because it contained rather more Unknown VI and less galactosamine than $P$. denitrificans). Hydrolysates of walls from the other species were used for making chromatographic comparisons of amino sugars.

Crude hexosamine-containing fractions were isolated from hydrolysates of walls from Pseudomonas putida, $P$. synxantha and $P$. fragi by high voltage electrophoresis, and were examined by descending paper chromatography using solvent system A. In addition to glucosamine, galactosamine and some basic amino acids, the fraction from $P$. putida had a ninhydrin-positive component with a mobility similar to that of mannose. The fraction from $P$. fragi contained glucosamine, galactosamine, basic amino acids and a ninhydrin-positive component with a mobility similar to that of galactose. The two unidentified components were isolated and shown, by using the AutoAnalyzer, to correspond to Unknowns IV and VI. Except for the absence of galactosamine, the hexosaminecontaining fraction from $P$. synxantha resembled that from $P$. putida on paper chromatography. However, the material isolated from the region of a chromatogram corresponding to Unknown IV was shown, by using the AutoAnalyzer, to contain both Unknowns IV and V. Chromatographic and electrophoretic data for the three compounds are given in Table I.

Table I. Chromatographic and electrophoretic properties of amino sugars

\begin{tabular}{|c|c|c|c|}
\hline \multirow[b]{2}{*}{ Analytical method } & \multicolumn{3}{|c|}{$R_{\text {glucossmine }}$} \\
\hline & Unknown IV & Unknown $\mathrm{V}$ & Unknown VI \\
\hline \multicolumn{4}{|l|}{ Paper chromatography* } \\
\hline Solvent A & $I .40 \pm 0.05$ & c. $1 \cdot 35$ & $I .2 I \pm 0.04$ \\
\hline Solvent B & $\mathrm{I} \cdot 80 \pm 0.05$ & c. $1 \cdot 70$ & $I .49 \pm 0.03$ \\
\hline Paper electrophoresis at pH 5.3 & $\mathrm{I} \cdot 06 \pm 0.02$ & c. $\mathrm{I} \cdot 06$ & $I \cdot 13 \pm 0.02$ \\
\hline Autoanalysis ( $21 \mathrm{~h}$. elution programme) & $1 \cdot 23 \pm 0.02$ & $1.27 \pm 0.02$ & $1.34 \pm 0.02$ \\
\hline
\end{tabular}

* A tendency to streak or form double spots was observed when solvents C, D and G were used.

Although purple spots were eventually formed for all three Unknowns after treating chromatograms with ninhydrin, the colours produced initially were: Unknown IV, greypink; Unknowns V and VI, brown. All three compounds reduced alkaline $\mathrm{AgNO}_{3}$ (Unknown $\mathrm{V}$ more strongly than Unknown IV) but gave no detectable reaction with aniline phosphate. Unknowns IV and VI gave a positive reaction with the Elson-Morgan reagents for 2-amino-2-deoxy sugars; Unknown $V$ seemed to give little or no colour, but a firm conclusion was not possible because of the poor separation from Unknown IV on chromatograms. The relatively high mobilities of the compounds on paper chromatograms suggested that they might be 6-deoxyhexosamines, and this was confirmed for Unknowns IV and VI. Both compounds gave positive reactions with reagents $\mathbf{A}$ (but not $\mathbf{B}$ or C) of Edward \& Waldron (1952), gave products with weak extinction maxima (relative to that for rhamnose) at about $400 \mathrm{~nm}$. in the cysteine- $\mathrm{H}_{2} \mathrm{SO}_{4}$ reaction, and gave acetaldehyde on oxidation with periodate. By assuming that the colour yields on reaction of Unknowns with ninhydrin were equal to that for glucosamine in order to calculate the amounts of amino sugars oxidized, the yields of acetaldehyde after $48 \mathrm{~h}$. were $71 \%$ (Unknown IV) and $79 \%$ (Unknown VI). By using the same assumption, the colour yields for Unknowns IV and VI, respectively, relative to those for glucosamine in an estimation of reducing sugars (Park \& Johnson, 
1949) were $90 \%$ and $85 \%$, and in an estimation of 2-amino-2-deoxyhexoses (Rondle \& Morgan, 1955) were $94 \%$ and $92 \%$. In the latter estimation, the extinction maximum (530 nm.) of the products from the Unknowns was the same as that for glucosamine.

A comparison of $R_{\text {glucosamine }}$ values (Table I) for Unknowns IV and VI with those reported for 2-amino-2,6-dideoxyhexoses (Lüderitz et al. 1968) was insufficient to identify the compounds. Comparisons of the Unknowns with authentic quinovosamine and fucosamine were therefore made by the following methods: $(a)$ descending, one-dimensional paper chromatography using solvent systems A, B, C, D and F, and ascending, two-dimensional paper chromatography using solvent systems $\mathrm{E}$ followed by $\mathrm{F} ;(b)$ high voltage paper electrophoresis at $\mathrm{pH}_{5 \cdot 3}$; (c) ion-exchange chromatography using the AutoAnalyzer; $(d)$ descending, one-dimensional paper chromatography of the $\mathrm{N}$-acetyl derivatives using solvent systems A, B and C; (e) descending, one-dimensional paper chromatography of the products of ninhydrin degradation using solvent systems $\mathbf{G}$ and $\mathrm{H} ;(f)$ high voltage paper electrophoresis in molybdate buffer of the amino sugar alcohols. In all tests Unknown IV had the properties of quinovosamine and Unknown VI those of fucosamine. The combination of methods used differentiates these amino sugars from other known 2-amino-2,6-dideoxyhexoses (Jann \& Jann, 1968; Lüderitz et al. 1968; Suzuki, 1969). The amounts of Unknowns available were too small for the determination of optical rotation or for confirmation of their identities by the ion-exchange technique of Crumpton (I959). However, by the latter technique using a column of Dowex 50 resin packed without the application of pressure, Unknown IV from the lipopolysaccharide of Pseudomonas stutzeri had $\boldsymbol{R}_{\text {glucosamine }} \mathrm{I} \cdot 38$ (S. G. Wilkinson and G. A. Lightfoot, unpublished results) as expected for quinovosamine (Wheat, I966). Although Unknowns IV and VI were not isolated from the walls of other species in which they occurred, limited studies on hydrolysates indicated that these components were the same as for $P$. putida and $P$. fragi. For example, ninhydrin degradation of hydrolysates of all walls containing Unknown IV gave rise to a new neutral sugar which reduced alkaline $\mathrm{AgNO}_{3}$, reacted with aniline phosphate to give a brown spot which had a strong blue-white fluorescence under ultraviolet light, and had the chromatographic mobility of 5-deoxyarabinose.

Although Unknowns IV and V were clearly separated using the AutoAnalyzer, a separation of the amino sugars (or their $\mathrm{N}$-acetyl derivatives) adequate for preparative purposes was not achieved. Consequently, studies on Unknown $\mathbf{V}$ have largely been confined to the mixture isolated from Pseudomonas synxantha. Like Unknowns IV and VI, Unknown V was reasonably stable to acid: it had first been detected in hydrolysates prepared using $6 \cdot \mathrm{I} \mathrm{N}-\mathrm{HCl}$ for $\mathrm{I} 6 \mathrm{~h}$. at $105^{\circ}$. This fact suggested that it was more likely to be a 2- or 3-amino sugar rather than a 4-amino sugar (Jann \& Jann, 1967). After ninhydrin degradation of the mixed Unknowns IV and V only 5-deoxyarabinose was detected. The possibility that Unknown $\mathrm{V}$ was rhamnosamine, which, like quinovosamine, would give 5-deoxyarabinose on degradation, was eliminated by electrophoresis of the amino sugar alcohols in molybdate buffer. Initially only 2-amino-2,6-dideoxyglucitol (from quinovosamine) was detected, but there was ionic interference with the detection of possible cationic spots. After removal of inorganic ions by prior electrophoresis in pyridine + acetic acid buffer $(\mathrm{pH} 5 \cdot 3)$, a second component was detected after electrophoresis in molybdate buffer. The mobility of this component $\left(R_{\text {glucosaminol }}-0 \cdot 29\right)$ suggested that it might be 3-amino-3,6-dideoxyglucitol ( $R_{\text {giucouaminol }}-0.3$ I Mayer \& Westphal, I968). The component was eluted and shown to yield acetaldehyde on oxidation by periodate. Further evidence that Unknown V was a 3-amino hexose was obtained by the method of Ashwell et al. (1965): the reactivity of the mixed $N$-acetyl derivatives of Unknowns IV and V with the Morgan-Elson reagents was 
significantly greater after periodate oxidation than before. The $\mathrm{N}$-acetyl derivative of quinovosamine would only react before oxidation, whereas the derivative of a 3-amino hexose would only react after oxidation. Unknown $\mathrm{V}$ could not be distinguished from authentic 3-amino-3,6-dideoxyglucose by the methods $(a)$ to $(f)$ used in the identification of Unknowns IV and VI.

\section{DISCUSSION}

Quinovosamine has previously been found in Achromobacter georgiopolitanum (Smith, I964; Colwell, Smith \& Chapman, 1968), strains of Salmonella, Arizona and Proteus vulgaris (Lüderitz et al. 1968), and Pseudomonas aeruginosa (Suzuki et al. 1970). In most cases the amino sugar has been shown to occur in lipopolysaccharides. Similarly, fucosamine has been identified as a component of lipopolysaccharides from Chromobacterium violaceum (Crumpton \& Davies, 1958), Escherichia coli (Ørskov et al. 1967) and P. aeruginosa (Fensom \& Gray, 1969; Suzuki, 1969) and of other bacterial polysaccharides. The location of these amino sugars within the cell wall was not studied during the present work, but further studies (S. G. Wilkinson, L. Galbraith and G. A. Lightfoot, unpublished results) have shown that quinovosamine occurs in the lipopolysaccharide fractions from $P$. stutzeri and $P$. syncyanea. Thus the present results and those of Suzuki (I969) indicate that 2-amino-2,6dideoxyhexoses may occur commonly in members of the family Pseudomonadaceae as well as in the Enterobacteriaceae. The occurrence of 3-amino-3,6-dideoxyglucose in $P$. synxantha and possibly in $P$. fluorescens is also of interest as 3-amino-3,6-dideoxyhexoses have been found in Xanthomonas campestris, a member of Pseudomonadaceae (Ashwell \& Volk, 1965), as well as in Enterobacteriaceae (Raff \& Wheat, 1966, I967; Jann, Jann \& Müller-Seitz, 1967; Lüderitz et al. 1967). The close similarity in composition between the walls of $P$. synxantha and $P$. fluorescens (both included in $P$. fluorescens as defined by Stanier, Palleroni \& Doudoroff, 1966) has been noted previously (Wilkinson, 1970). The present results underline the basic similarity in composition between lipopolysaccharides from pseudomonads and from members of the Enterobacteriaceae.

We thank the following for valuable gifts of reference materials: Dr J. A. Cifonelli, Department of Biochemistry, University of Chicago, Chicago, U.S.A. (for the specific polysaccharide from Pneumococcus type XII); Dr O. Lüderitz, Max Planck Institut für Immunbiologie, Freiburg, Germany (for fucosamine); Dr A. C. Richardson, Department of Chemistry, Queen Elizabeth College, University of London (for 3-amino-3,6-dideoxyL-glucose); Dr R. W. Wheat, Department of Microbiology and Immunology, Duke University, Durham, North Carolina, U.S.A. (for quinovosamine).

\section{REFERENCES}

Ashwell, G., Brown, N. C. \& Volk, W. A. (1965). A colorimetric procedure for the determination of $N$-acetylated-3-amino hexoses. Archives of Biochemistry and Biophysics 112, 648-652.

Ashwell, G. \& Volk, W. A. (1965). Isolation of $N$-acetyl-3-amino-3,6-dideoxy-D-galactose, a cell wall constituent of Xanthomonas campestris. Journal of Biological Chemistry 240, 4549-4555.

Avigad, G. (1969). Rapid, sensitive determination of periodate. Carbohydrate Research rI, I I9-I 23.

Cifonelli, J. A., Rebers, P., Perry, M. B. \& Jones, J. K. N. (I966). The capsular polysaccharide of Pneumococcus type XII, SXII. Biochemistry 5, 3066-3072.

Colwell, R. R., Smith, E. J. \& Chapman, G. B. (1968). Properties of a D-quinovosamine-producing Achromobacter. Canadian Journal of Microbiology 14, 165-171.

Crumpton, M. J. (I959). Identification of amino sugars. Biochemical Journal 72, 479-486. 
Crumpton, M. J. \& Davies, D. A. L. (1958). The isolation of D-fucosamine from the specific polysaccharide of Chromobacterium violaceum (NCTC 7917). Biochemical Journal 70, 729-736.

Dische, Z. (1962). Colour reactions of 6-deoxy-, 3-deoxy- and 3,6-dideoxyhexoses. In Methods in Carbohydrate Chemistry, vol. I, Analysis and Preparation of Sugars, pp. 50I-503. Edited by R. L. Whistler \& M. L. Wolfrom. New York: Academic Press.

EDWARD, J. T. \& WALDRON, D. M. (1952). The detection of deoxy sugars, glycals, and methyl pentoses in paper partition chromatography. Journal of the Chemical Society, pp. 363I-3634.

Fensom, A. H. \& Gray, G. W. (I969). The chemical composition of the lipopolysaccharide of Pseudomonas aeruginosa. Biochemical Journal rr4, 185-196.

JANN, B. \& JANN, K. (1967). 4-Amino-4,6-dideoxyhexoses isolated from lipopolysaccharides of Escherichia coli. European Journal of Biochemistry 2, 26-31.

JANN, B. \& JANN, K. (I968). 2-Amino-2,6-dideoxy-L-mannose (L-rhamnosamine) isolated from the lipopolysaccharide of Escherichia coli 03:K2ab(L):H2. European Journal of Biochemistry 5, I73-177.

JANN, B., JANN, K. \& MülLER-SeItZ, E. (1967). A 3-amino-3,6-dideoxyhexose from the lipopolysaccharide of Escherichia coli $07 \mathrm{I}$. Nature, London 215, 170-I7I.

KABAт, E. A. \& MAYER, M. M. (196I). Experimental Immunochemistry, 2nd edn, p. 549. Springfield, Illinois: Charles C. Thomas.

Lüderitz, O., Gmeiner, J., Kickhöfen, B., Mayer, H., WestPhal, O. \& Wheat, R. W. (1968). Identification of D-mannosamine and quinovosamine in Salmonella and related bacteria. Journal of Bacteriology 95. 490-494.

LÜDERITZ, O., JANN, K. \& WHEAT, R. (1968). Somatic and capsular antigens of Gram-negative bacteria. In Comprehensive Biochemistry, vol. 26A, Extracellular and Supporting Structures, pp. 105-228. Edited by M. Florkin \& E. H. Stotz. Amsterdam: Elsevier Publishing Co.

Lëderitz, O., RuschmanN, E., Westphal, O., RafF, R. \& Wheat, R. (1967). Occurrence of 3-amino-3,6dideoxyhexoses in Salmonella and related bacteria. Journal of Bacteriology 93, I68I-I 687 .

Mayer, H. \& WestPhal, O. (1968). Elektrophoretische Trennungen von Hexosamin- und Hexuronsäurederivaten als Molybdatkomplexe. Journal of Chromatography 33, 5I4-525.

ØrSkov, F., Ørskov, I., JANN, B., JANN, K., Müller-Seitz, E. \& WestPhal, O. (1967). Immunochenistry of Escherichia coli $\mathrm{O}$ antigens. Acta pathologica et microbiologica scandinavica 7r, 339-358.

PARK, J. T. \& JOHNSON, M. J. (I949). A submicrodetermination of glucose. Journal of Biological Chemistry I8I, I $49-15 \mathrm{I}$.

PARTRIDGe, S. M. (1948). Filter-paper partition chromatography of sugars. I. General description and application to the qualitative analysis of sugars in apple juice, egg white and foetal blood of sheep. Biochemical Journal 42, 238-248.

RAFF, R. A. \& WHEAT, R. W. (1966). Occurrence of a 3-amino sugar in the cell wall of Citrobacter freundii 8090. Biochimica et biophysica acta 127, 27I-273.

RAFF, R. A. \& WheAT, R. W. (I967). Characterization of 3-amino-3,6-dideoxy-D-glucose from a bacterial lipopolysaccharide. Journal of Biological Chemistry 242, 4610-4613.

RondLe, C. J. M. \& MorGan, W. T. J. (1955). The determination of glucosamine and galactosamine. Biochemical Journal 6r, 586-589.

Simmons, D. A. R. (1969). The immunochemistry of Shigella flexneri $\mathrm{O}$ antigens. The structure and biosynthesis of the O-specific side chains of some representative serotypes. European Journal of Biochemistry II, $554-575$.

SмIтн, E. J. (1964). The isolation and characterization of 2-amino-2:6-dideoxy D-glucose (D-quinovosamine) from a bacterial polysaccharide. Biochemical and Biophysical Research Communications 15, 593-597.

SPIRO, R. G. (1966). Analysis of sugars found in glycoproteins. In Methods in Enzymology, vol. viI, Complex Carbohydrates, pp. 3-26. Edited by E. F. Neufeld \& V. Ginsburg. New York: Academic Press.

Stanier, R. Y., Palleroni, N. J. \& Doudoroff, M. (1966). The aerobic pseudomonads: a taxonomic study. Journal of General Micobiology 43, I59-27I.

Sirominger, J. L., Park, J. T. \& ThOmpson, R. E. (1959). Composition of the cell wall of Staphylococcus aureus: its relation to the mechanism of action of penicillin. Journal of Biological Chemistry 234, $3263-3268$.

SuzukI, N. (1969). Isolation of DL-fucosamine from Pseudomonas aeruginosa N10. Biochimica et biophysica acta $177,37 \mathrm{I}-373$.

SUzUKI, N., SuzUKI, A. \& FukasaWa, K. (1970). Distribution of 2-amino sugars in Pseudomonas aeruginosa; isolation of D-quinovosamine from P. aeruginosa PI4. Journal of the Japanese Biochemical Society 42, I 30-I 34 . 
Trevelyan, W. E., Procter, D. P. \& Harrison, J. S. (1950). Detection of sugars on paper chromatograms. Nature, London 166, 444-445.

WhEAT, R. W. (I966). Analysis of hexosamines in bacterial polysaccharides by chromatographic procedures. In Methods in Enzymology, vol. vin, Complex Carbohydrates, pp. 60-78. Edited by E. F. Neufeld \& V. Ginsburg. New York: Academic Press.

Wilkinson, S. G. (1970). Cell walls of Pseudomonas species sensitive to ethylenediaminetetraacetic acid. Journal of Bacteriology r04, I035-1044. 